\section{Birlesik Dünya Arastırma Cypriot Journal of Educational \\ BD-CENTER \\ Sciences}

Innovasyon ve Yayıneılık Merkezi
Volume 16, Issue 6, (2021) $3168-3183$

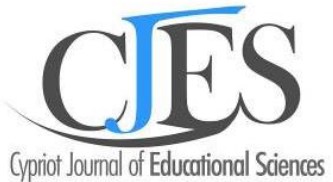

www.cjes.eu

\title{
Analysis of professional competencies and basic skills in distance education tutor tutorials
}

\author{
Muhammad Arifin Zaidin*, UPBJJ-Open University Makassar, South Sulawesi, 90221 Indonesia, \\ https://orcid.org/0000-0001-9692-8804 \\ Kusmaladewi Kusmaladewi, UPBJJ-Open University Makassar, South Sulawesi, 90221 Indonesia, \\ https://orcid.org/0000-0002-2765-3293
}

Aziz Thaba, Lembaga Swadaya Penelitian dan Pengembangan Pendidikan Matutu, Makassar, South Sulawesi, 90221 Indonesia, https://orcid.org/0000-0002-3340-2925

Zaidin, M., Kusmaladewi, K., \& Thaba, A., (2021). Analysis of professional competencies and basic skills in distance education tutor tutorials. Cypriot Journal of Educational Science. 16(6), 3168 - 3183. https://doi.org/10.18844/cjes.v16i6.6531

Received from September 05, 2021; revised from November 15, 2021; accepted from December 15, 2021.

(C)2021 Birlesik Dunya Yenilik Arastirma ve Yayincilik Merkezi. All rights reserved

\begin{abstract}
This study aims to examine how the ability to apply professional competency tutors and how the ability to apply basic skills tutorial tutors Early Childhood Education Program in the Makassar Open University Distance Learning Program Unit. This research is type of qualitative research. Research sample consisted of six tutors as key informants. Purposive sampling technique is used with the consideration of key informants in the level II regional pokjar. Data analysis used four stages, namely identification, data reduction, interpretation, explanation, and conclusion. The results of this study indicate that tutors have tutorial readiness, tutors do not check module readiness and do not convey special competencies (KK), the presentation of material is still not optimal. The tutor does not provide apperception, the tutor is flexible and positive in the tutorial, presents the material using power points, the tutor has not maximized the assessment process or learning outcomes.
\end{abstract}

Keywords: Basic, competence, application, professional, skills, tutorial;

\footnotetext{
* Address of correspondence: Muhammad Arifin Zaidin, UPBJJ-Open University Makassar, South Sulawesi, 90221 Indonesia, Email address: abdullah.anishm@gmail.com, sanjaysainipilani35@gmail.com
} 


\section{Introduction}

Serving and maintaining the growth of the soul, heart, feelings and character is a goal of education. Which education is one of the efforts taken by humans to develop their abilities or competencies, both physically and spiritually in accordance with the values contained in social and culture. The purpose of education to be achieved is, so that every ability or potential possessed by each individual experiences development so that it is useful for his survival, be it as an individual, as a citizen or citizen.

Education is the main key in managing the quality of academic and non-academic life and in the process and results of education can realize one's personal competence by involving the ability of knowledge, understanding ability, ability skills, behavior, and values, and the last interest. The combination of competency indicators strengthens the improvement in the quality of work performance. Tutors with their competence become a capacity to do the work they carry inclusive work doing tutorials. Competence is the capacity of self that embodies a personal responsibility and has a representation of the quality of learning achievement from a student tutorial process of early childhood education teacher education programs.

The implementation of competencies is the forerunner of professional competencies whose essence is more focused on planning, implementation, and assessment based on material abilities, composition, ideas, and scientific patterns, mastery of standard scientific competencies according to educational background, and development is carried out creatively, sustainably without neglecting digitalization. Tutor professional competence becomes a reference of his professionalism so that the ability to understand professional competency is seen.

One part that is inseparable from the professionalism of tutors in applying tutorial competencies, namely the ability to implement the basic skills of a tutorial tutor in the tutorial process. The tutorial tutor's basic skills in the tutorial process are important for the tutor to carry out in the tutorial because besides building a conducive academic atmosphere, tutorials also provide attention and persistence to the tutor's tutorial on the ability to ask questions, provide support, and make variations, able to provide explanations, and able to provide an opening and closing the tutorial, being able to direct group discussions, being able to organize classes, and being able to teach groups and individuals The basic skills indicator of this tutorial is a requirement for tutors to be understood and implemented both theoretically and practically.

Intensification of competency understanding, professional competency, and basic tutorial skills is very important in tutorial activities so that researchers are inspired to explore how much understanding the tutor has related to competencies, professional competencies, and basic tutorial skills in the form of research studies of professional competency analysis basic tutorial tutor skills PG PAUD at UPBJJ UT Makassar.

\section{Literature Review}

\subsection{Competence}

Competence is the personal aspects of every employee who is able to achieve superior performance targets. As for those which include personal aspects, namely, aspects of nature, aspects of motives, aspects of the value system, aspects of attitude, aspects of knowledge and aspects of skills where the abilities or competencies of each individual will be able to direct behavior, and behavior will produce the performance. LOMA Competency Dictionary 1998 Lasmahadi, (2000). According to Susanto (2012). Competencies that are always used are the characteristics that underlie each individual in terms of achieving superior performance. In addition, competence is also defined as the knowledge, skills and abilities related to work, as well as the expertise needed in all non-routine jobs. 
Ashton (1991) also explains about competency standards that one's competence is not enough based only on experiences but also other assessments are needed in producing good decisions because humans still have several other elements besides experience. Thoha \& Hutapea (2008) competence is a measure owned by each individual that can make each individual able to meet the various requirements made by work in an organization so that the organization is able to reach the target Competence is the basic. Everyone's quality who has a connection with the cause and effect of achieving extraordinary work with effective work.

Some limitations of the above competencies can be underlined that competence is a personal aspect of each individual who is likely to achieve superior performance by emphasizing knowledge, skills (attitude), and behavior (attitude), as well as productive behavior that must be possessed to demonstrate in order achieve extraordinary work results or work effectiveness.

\subsection{Profession, Professional, Professionalism, Professionalism}

A profession is a job that has a relationship with a particular field (expertise, skills and technique), which we know if a person has good expertise, the more professional the job is. Which is the professional persons who take care of the profession in his work. Where professionalism is a condition, direction, values, goals, along with the quality of expertise and authority related to one's livelihood, professionalism is more directed to commitment as a member of a profession that aims to continuously improve his professional abilities. Professionalism is the act of someone professional who always upholds the ability of his proposition, someone professional has an attitude that always upholds his professional expertise, and someone professional will always work and do work in accordance with his professional field. We can see the professionalism of a worker by looking at the lifelong learning process, which is a factor that can affect the recognition of professional positions (Saudagar, 2009).

Samini (2019) argues that professional competence is the ability of someone who masters knowledge in the fields of science, technology and / or art which he supports with mastery as follows: (a) Learning material that is broad and deep must be in accordance with the standard content of the program in accordance with the field covered; (b) The field of science, technology, and / or art has concepts and methods that are interrelated with the education unit program that it supports; Ziyad Tarik Maki (2021) mention that profession is a type of occupation able to make distinctive or special claims about its work practices and status. A professional is a member of a profession (may or may not involve formal registration), and Professionalisation describes the process that results in an occupation becoming a profession. Furthermore, Sykes (1980) in Muhammad Aiman Arifin (2021) defines 'competence' and 'competence' as the ability to perform tasks and this definition is easily interchangeable with others. Van Merriënboer and Kirschner (2017) in Eva Pupíková, Dalibor Gonda, Kitti Páleníková, Janka Medov , Dana Kolárová, and Anna Tirpáková (2021) define competence as "a combination of complex cognitive and higher abilities, highly integrated knowledge structures, interpersonal and social skills and attitudes and values".

Professional competence includes the concept of personal capabilities, innovators, with the criteria of commitment to professionalism, as well as being able to provide development and explanation of the goals of science in survival, able to explain theoretical and practical dimensions, able to educate creative, able to be role models, and able to be responsible. Zdenka Gadušová,, alena Hašková,\& Ĺubica predanocyová (2021) states that competence and internal structure are the basis for the development of evaluation tools. A design philosophy is a tool based on the application of humanistic aspects and the fact that in the evaluation process the evaluated teacher should not feel threatened by the evaluator, but must feel a real interest in helping to find the right solution along with the other. 
Zaidin, M., Kusmaladewi, K., \& Thaba, A., (2021). Analysis of professional competencies and basic skills in distance education tutor tutorials. Cypriot Journal of Educational Science. 16(6), 3168 - 3183. https://doi.org/10.18844/cjes.v16i6.6531

\subsection{Basic Skill Tutorial}

Darmayanti \& Sumantri (2004) mastery of basic tutorial skills will create a conducive implementation of the tutorial, which is goal-oriented and has high effectiveness and efficiency. The basic skills of tutorials that must be understood by tutors are as follows. Richard J. Shavelson (2014) difines that any teaching act is the result of a decision, whether conscious or unconscious, that the teacher makes after the complex cognitive processing of available information. This reasoning led to the hypothesis that the basic teaching skill is decision making. Moerdianto (2017) in Arifmiboy (2019) explained that microteaching learning is directed at the formation of competencies based on the Government Regulation Number 19 of 2005 concerning on National Education Standards, in which Chapter VI article 3 contains that teacher competencies include: (1) pedagogical competence, (2) personality competence, (3) professional competence, and (4) social competenc It was further concluded that Muhlis H. Usman, Agil Al Idrus1, Aris Doyan, Harry Soeprianto, Aliefman Hakim (2021) Basic teaching skills are a general characteristic of someone related to knowledge and skills that are manifested through action. Basically, basic teaching skills are in the form of basic and specific forms of behavior that a teacher must have as initial capital to carry out his teaching tasks in a planned and professional manner.

\subsubsection{The Skill of Asking Questions}

The skill to ask questions is very important for every tutor because by applying effective and efficient questioning skills in the course of the tutorial process will be able to improve the ability of students to have an opinion, be able to accept and expand knowledge skills, and be able to advance motivation to actively participate in tutorial. Then, the skill of asking questions consists of two, including basic asking skills (BAS) and advanced asking skills (AAS). BAS consists of the following components: (a) Ask questions briefly and clearly so that students easily find answers; (b) Focusing attention: usually contains questions leading to the problem; (c) Spread the questions throughout the class, then ask specific students to answer; (d) Give thinking time and guidance by simplifying questions, setting examples, or repeating statements entirely;

AAS have factors including: (a) It is better if the questions asked are not memorized but in accordance with higher cognitive abilities because they are able to train our way of thinking; (b) The questions should be arranged in advance from questions that have a low cognitive level to higher cognitive questions; (c) Finally use tracking questions and create interactions between tutors and students or between students, for example throwing questions from students to students. Seung Min Han, Pylin Parkes, \& Susannah Wang (2021) explan that hhe study's question, listen, respond" conceptual framework encourages teachers to assess students' responses (listen) and tailor their next question to improve learning (respond). Participants'satisfaction may not be due to the increased number or type of questions alone,but how the questions were asked, such as the attendings' use of body language orappropriateness of the topic.

\subsubsection{Strengthening Skills (SS)}

Strengthening the skill of asking is the ability to think high. Brierton, et.al, (2016) in Luthfiyah Nurlaela, NugrahaniAstuti, Ita Fatkhur Romadhoni, Niken Purwidiani, Sri Handajan (2019) explain that developing higher-order thinking skills in students is an important task for higher education. Students who have the competence to analyze, synthesize, and evaluate, will better be prepared to face the challenges of the work they will face. Giving reinforcement is a tutor's response to a student's action that most likely the student will repeat the action. There are two ways that can be done to provide reinforcement, namely verbal reinforcement and nonverbal reinforcement. What is meant by verbal reinforcement is reinforcement in the form of sentences of praise, while nonverbal reinforcement is reinforcement in the form of expression, approaching, body language, nodding, and so on. In providing reinforcement must be 
considered are: must be warm and enthusiastic, meaningful, clear, certain groups, varied, and avoid negative responses.

\subsubsection{Skills for Making Variations (SMV)}

To reduce boredom of students, tutorial activities need to be given varied tutorials. The variety styles of teaching include: making eye contact, making silence, focusing attention, variety of sounds, and variations in body language and expression. Media variations are: visual, auditive, and tactile and manipulation variations. Variations in interactions and activities include: classical interactions.

\subsubsection{Explaining Skills (ES)}

Explaining skills is something that must be owned by teachers or tutors because it is part of education. Sixson Roberto Simangunsong, Sabda Dian Nurani Siahaan, Dodi Pramana. (2020). Say that education is said to be successful if it can provide the ability, knowledge and skills to graduates to continue higher education or enter the world of work. This skill is the activity most often done by tutors during the tutorial. Activities that need to be carried out in explaining skills include: guiding students to understand tutorial material, answering questions, encouraging active thinking, and helping to experience various reasoning processes. Explaining skills can be given at the beginning, middle, end of the tutorial as needed, relevant to the purpose, meaningful, and according to the ability of students.

\subsubsection{Open and Close Tutorial Skills (OCTS)}

The appearance of opening and closing learning (Set instruction and Closure) mentioned Susantini (2014: 14) in Hera Deswita (2017) that the activity of opening learning is an activity carried out by teachers to create mental-ready situations and prepare students to focus their attention on what is learned. This skill needs to be possessed by a tutor. The skill to open a tutorial is the activity of a tutor to provide an introduction or direction on the material to edit so that students are interested in following it, and should have a clear picture of the tutorial material that will be given and must be mastered at the end of the tutorial.

Some skill factors in opening a tutorial are: attracting the attention of students, fostering motivation, (enthusiasm, interesting), giving examples of tutorial descriptions, and linking topics that are already mastered with new topics of discussion. While closing tutorial skills are the basic skills to summarize the core material that has been written at the end of the tutorial or the end of a learning activity or one module. The activities that can be carried out are summarizing, summarizing the core material, giving psychological encouragement, conducting evaluations, and giving further assignments.

\subsubsection{Skills in Guiding Small Group Discussions (SGSGD)}

SGSGD is one form of teaching activities with characteristics: 3-9 per group takes place in face-to-face interactions has goals to be achieved, take a place systematically. Small groups allow for a variety of information and experiences, increase understanding of important issues, and foster healthy, cohesive and responsible cooperation

\subsubsection{Class Management Skills (CMS)}

Reka Rahayu, Ratnawati Susanto (2018) concluded that classroom management has a positive and significant influence on students' learning activities. CMS is a skill to create and maintain optimal classroom conditions so that a harmonious and effective teaching-learning process occurs. In CMS requires mastery, 
among others: encouraging the development of individual responsibilities in behaving in accordance with the rules and activities that are ongoing, as well as providing an active response to student behavior.

\subsubsection{Small Group and Individual Teaching Skills (SGITS)}

AlMegbil,T. (2020) explain that small-group not defined by number - no one right size. It is teaching situation in which dialogue \& collaboration within the group are integral to learning .Teacher has a key role as to facilitate rather than direct, coordinate as much to communicate, inspire rather then inform, and $A$ collection of individuals is not a group until they interact (https://www.researchgate.net/publication). Small-group instructional organization is a group setup aimed at instructing the same skills or a combination ofdifferent skills to at least two students with the same or different learning and performance characteristicsMastery of SGITS enables tutors to manage activities effectively and efficiently and play their roles as follows: organizational teaching and learning activities, sources of information, encouraging learning, material providers, admitting and providing assistance as needed, and having rights and obligations.

The eight basic tutorial skills are very important to be understood and implemented by tutors in the tutorial because the benefits are not only creating conducive tutorials, academic authority, but triggering and spurring tutorial creativity which leads to improving the achievement of PG PAUD students in UPBJJ UT Makassar.

\section{Research Methods}

\subsection{Types of Research}

This study uses qualitative research methods because the data obtained are sourced from reality on the ground without changing the shape or form of data modification. The data obtained remains the original form until the data processing stage. Therefore, qualitative research deals with paradigms that are subject to reality on the ground rather than what was thought subjectively from the start Bungin, (2007).

Suwendra (2018) qualitative descriptive research is research that does not intend to test hypotheses but only describes what they are about a variable, phenomenon or condition. Descriptive method can be interpreted as a problem solving procedure that is investigated by describing or describing the state of the subject or object of research at the present time based on facts that appear or as they are.

\subsection{Research Sample}

Sampling is done with certain considerations (purposive sampling) with considerations besides the key informants being in the districts and cities as well as time efficiency. As such, the study does not question the number of samples as long as the determination of key informants and the complexity of the phenomena under study are correct. The sample set by the researcher, the researcher set six tutors as key informants in the districts of Tana Toraja, Takalar, Soppeng, Pinrang, and Jeneponto. Each district has one tutor as a key informant.

\subsection{Data Collections Technique}

Data collection techniques in this study are based on the type of data, namely qualitative data in the form of professional competence and basic skills tutorial. Because this research is a qualitative study, the data collection techniques used are observation and interview techniques. As for the mechanism of data collection, the researcher made observations in the tutorial class when the tutor (key informant) 
conducted a 120-minute tutorial by observing the emergence of indicators and sub-indicators of professional competency tutorials and basic skills of tutorial tutors.

\subsection{Data Analysis Technique}

Sugiyono (2013) qualitative data analysis is conducted interactively and continues continuously until completion. The data obtained were analyzed intact and produced conclusions made during the study. Data analysis was carried out in the stages of identification, data reduction, interpretation, presentation, and conclusion.

\section{Results and Discussion}

\subsection{Test Validity and Reliability KP}

To test whether the instrument used, in this case the questionnaire met the validity requirements, basically Pearson correlation was used. The method of analysis is by calculating the correlation coefficient between each value in the question number with the total value of the question number. Furthermore, the correlation coefficient obtained by $r$ still needs to be tested for significance by using the test or comparing it with $r$ tables. If $t$ arithmetic $>$ from $t$ table or $r$ arithmetic $>$ from $r$ table, then the question number is valid. When using a computer program, provided that the $r$ obtained is followed by a price of $p$ $<0.05$ means the number of questions is valid (Sanusi, 2010). From the results of calculations using SPSS 22 , all variables get results $p<0.05$, so it can be concluded that all the variables are declared valid.

The instrument reliability test was performed using the Cronbach alpha technique with the reliability criteria of a variable construct expressed as good if it had a Cronbach's Alpha value $>0.60$ (Santoso, 2018). Based on the results of calculations using SPSS 22, the reliability results obtained can be seen in Table 1.

Table 1. Result of Test Reliability Statistics

\begin{tabular}{cc}
\hline Cronbach's Alpha & N of Items \\
\hline .870 & 20 \\
\hline
\end{tabular}

Based on the calculation results in Table 1 above, it can be seen the value of Cronbach's Alpha ( $\alpha$ ) obtained 0.870 , it can be concluded that the reliability results are stated "Good".

\subsection{Test Validity and Reliability KDT}

Validity test depends on the type of data used. In this study, the instrument uses a dichotomous scale $[1,0]$, then the validity test used is the r-Point Biserial test, abbreviated as r-pBis Muhidin, (2017). The criterion used for the item validity test is the comparison between the biserial point correlation coefficient ( $r$-pBis) and rtable at $a=0.05$, where if $r$-pBis is greater than rtable then the item is considered valid. Whereas if $r$-pBis is smaller or equal to rtable then the items are considered invalid and subsequently deleted or not used in research (Arief \& Srihastuti, 2017). From the results of calculations using Microsoft Excel, the value of rcount ( $r$-pBis) is compared with the value of rtable $=0.197$, the results of the validity test show there are 11 questions and 13 invalid questions from the 24 questions presented. The invalid question items are then deleted and not used in the study.

According to Darmayanti \& Sumantri (2004), to determine the reliability of the test in the form of multiple choice (dichotomous), the KR-20 formula can be used. According to Fraenkel, Wallen, \& Hyun (2012), an instrument is declared reliable if the value of the KR reliability coefficient is more than 0.70 ( $r>$ 0.70). Based on calculation used the KR-20 formula, the $r$ value of 0.978 shows that 11 reliable research questions are used. 


\subsection{Description of Research Results}

\subsubsection{Application of Professional Competency Tutors (APCT)}

Study on PKPT in the form of:

\section{a. Management of Tutorial Preparation}

Management of tutorial preparation related to the attention of course characteristics, types of tutorial activities, tutorial time and tutorial environment. The results of the observation show that the submanagement of the tutorial preparation has been prepared before doing the tutorial so that it will facilitate and simplify the tasks they carry.

b. Implementation of Tutorial Activities

The procedure of implementing the tutorial is related to the tutorial activity that must be done when the tutor makes a tutorial in the tutorial room, namely the tutor gives an opening greeting, checks attendance and student modules, provides motivation, explains the specific competencies, benefits and scope of the material, assignments to be given, invites students ask questions, show a description of the system, active communication, the conclusion of the tutorial results, confirmation of the summary of the material, the opportunity to ask questions, and giving follow-up.

The tutorial implementation sub indicator is conducted by the tutor when the tutorial is, there are still sub indicators that have not been maximized, such as the tutor does not check the readiness of student modules, does not convey special competencies, the benefits and scope of the material, the use of methods, the sequence and relevance of the material, and does not make a summary of the material.

\section{c. Management of Material Presentation}

Sub-indicators of the management of the presentation of the material include: decomposition of the material, examples of exercises, determination of the method, review, response to questions, positive responses, rotating questions, feedback, oral expressions, written, signaling, communicative language, apperception of material, stimulating passive students, asking questions open, giving positive responses, and involving students in making summaries.

The results of observations show that the sub-indicators of the management of the presentation of material are still not optimal. For example, the suitability of the method with the material is not linked (link), does not review the responses of inappropriate answers, does not provide apperception do not involve students in summarizing, summarizing, and reviewing the material.

d. An Attitude of Flexibility and a Positive Towards Students

The tutor's flexibility and positive attitude towards students when presenting material by the tutor is related to facial expressions, voice intonation, atmosphere, problem solving, guidance, cooperation between students, opportunities to express opinions or reasons, verbal and nonverbal praise, achievement support, invitation to know oneself, time management, good learning techniques, learning resources, and good work assignments.

e. Presentation Materials

Presentation materials and learning resources related to the use of power points in explaining KK, MK characteristics, time allocation, methods, clear understanding of the material, mind concentration, reading interest, and learning atmosphere. Presenting tutorial material through power points is a conditional requirement for students and tutors in order to sharpen the attractiveness of students. This is evidenced when the tutorial observations are made the tutors have prepared and done so with power points. 


\section{f. Process Assessment, Learning Outcomes, and Closing}

The assessment of the learning process and outcomes relates to impression questions, training, performance demands, student responses, assignments, the ability of demonstration, provision of tests, and questions and answers. The results of the observation show that the tutor conducts an assessment of the process and learning outcomes, except that the student's impression of the tutorial process has not been done by the tutor during the tutorial. Then in the closing activity, not all tutors concluded, reviewed the material with the students, while the next tutorial readiness tutors gave reading assignments in their respective homes.

g. General Impression Tutorial Discussion of material according to the KK, the presentation of the material, the use of Standard Indonesian, and the appearance of the tutor have been done by the tutor when doing the tutorial in the tutorial room.

\subsubsection{Basic Skills Competency Tutorial}

a. Basic Questioning Skills (BQS)

BQS includes asking short and clear questions, focusing, distributing questions, and giving time to think when implementing the tutorial. During the 120 minutes the researcher paid attention to the tutor (key informant) in the tutorial room, the tutor did not utilize the basic questioning skills of the students, even the distribution of questions to the whole class was done very little by the tutor.

b. Advanced Questioning Skills (AQS)

AQS includes asking questions in the cognitive form, questions with a convex level, tracking questions, and interactive questions. Not all tutors do KBL when implementing tutorials. Very few tutors make use of questions that demand students' cognitive abilities, and tracking questions among students.

c. Strengthening Skills (SS)

SS is related to providing verbal and verbal reinforcement, as well as varied tutorial styles. Observation results showed that not all SS sub-indicators did the tutors during the tutorial. Even very few tutors make use of varied tutorial style skills so that it seems very monotonous.

d. Skill of Variation (SV)

SV is concerned with the way the tutor variations the tutorial style and how the tutor initiative uses variations in the media. The results of observations made by researchers note that very few tutors make use of variations in tutorial styles and variations in media when tutorials.

e. Explaining Skills (ES)

ES is related to the ability to use straightforward and easy language, examples of each topic, emphasis on material, structure of material presentation, and exercises and feedback from students. Tutors are generally able to do KM well when tutorials, it's just that in the realm of back explanation is still not done by tutors when implementing tutorials.

f. Opening and Closing Skills (OCS)

OCS includes activities of opening greetings and closing words. The observations show that all tutors have done well.

g. Skills for Guiding Small Group Discussions (SGSGD)

SGSGD is related to the formation of small discussion groups by paying attention to the components of concentration skills, clarity of discussion issues, analysis of views, dissemination of participation, 
and closing of discussions. Class observations carried out for 120 minutes showed that the application of KMDKK was still lacking in the tutor's attention.

h. Class Management Skills (CMS)

This CMS includes creating and maintaining tutorial conditions, class atmosphere, and handling deviant behavior. The observations show that all tutors can manage tutorial classes when doing tutorial activities.

\subsection{Discussion of Research Results}

Discussion of research results includes the application of professional competencies and basic skills of tutor tutorials with their sub-indicators.

\subsubsection{Application of Professional Competency Tutors (APCT)}

a. Tutorial Preparation

Tutor tutorial preparation is done before implementing the tutorial. The determination of tutorial preparation refers to the tutorial method. The method functions to inspire preparation. The instrument that tutors need to prepare before the tutorial is the tutor must understand how the character of the course, what type of tutorial will be used, how the mechanism of using time, and the tutorial environment. Thus, the method function helps the implementation of the tutorial. Related to the function of the method, in the book Science and Education Application Part 2 Fip-Upi, (2007) stated that the function of the method is to help learners learn with the learning formula:

\section{$P b=f p=(f b(m S b k p)$}

\begin{tabular}{clll}
\hline $\mathrm{Pb}$ & $=$ learning & $\mathrm{f}$ & $=$ function \\
$\mathrm{M}$ & $=$ learn & $\mathrm{s}$ & $=$ learners \\
$\mathrm{B}$ & $=$ teaching materials & $\mathrm{k}$ & $=$ output \\
$\mathrm{P}$ & $=$ influence (outcome) & & \\
\hline
\end{tabular}

The characteristics of the learning method are flexible, open, and participatory.

b. Implementation of Tutorial Activities

In the preliminary activity, the tutor carries out the opening greeting activity, checks the presence and readiness of the module, explains the specific competencies of the tutorial, outlines the benefits and scope of the material, and conveys the type of tutorial assessment. Then at the presentation stage, the tutor asks questions, sequences systematic activities, communicates effectively, provides opportunities to ask questions, and provides follow-up. The implementation of the tutorial refers to the tutorial unit plan (SAT) that is made and carried out per each tutorial and is inseparable from the tutors' responsibilities and initiatives.

Tutors accept tutorial assignments as a responsibility. This is in line with the opinion of K. Bertens (1993) that being responsible means being able to answer when asked about the actions carried out. The person responsible can be asked for an explanation of his behavior and not only can he answer if he wants, but he must also answer. Responsibility means that people should not evade, when asked for an explanation of their actions. Ananta (2018) responsibility is to be prepared to accept obligations or duties. The negligence of the tutor does not convey the specific competencies (KK) to be achieved 
in the tutorial, does not check the readiness of the student modules, and does not describe the benefits and scope of the material, the use of methods, the sequence and relevance of the material, and the material summary is the tutor's responsibility that cannot be ignored in a tutorial activity.

Basically tutors not only have responsibilities but also initiative, only initiatives that they have are not well explored, for example ignoring the delivery of special competencies during the tutorial.

\section{c. Class Management Tutorial}

Describe, give examples, conduct reviews, respond to questions, provide positive responses, spread questions, offer oral and written expressions, encourage passive students, ask open-ended questions, In principle tutors conduct sub-indicators of classroom management properly, only between methods and materials out of sync so that it seems monotonous. The tutor also does not provide a review of incorrect answers, does not involve students in summarizing, and summarizes what causes tutors to monopolize time. The portion of time for students is greater than the portion of tutor time, which is $80 \%$ of time for students and $20 \%$ of time for tutors. Time management in accordance with the portion will create a more interesting tutorial atmosphere.

Brown \& Race (2013) explains the use of time management in a tutorial in a way:

(1) Help students see what's in time management in the tutorial; (2) make them think consciously about successful learning; (3) help them to stop and look back; (4) help them to set aside from the effects of time delay; (5) direct them to set learning deadlines for themselves; (6) help them feel positive about going beyond schedule; and (7) ask them to do a risk assessment; (8) help them maximize the use of their colleagues; and (9) ensure that minutes can be counted more than hours.

\section{d. Flexibility and Positive Attitude}

Appearance with facial expressions, voice intonation, learning atmosphere, classroom management, mentoring, communication between students, expression of student opinions, support or encouragement, self-concept, time management, learning techniques, search for learning resources by tutors, although providing opportunities for expression of opinions and problem solving Not done by tutors. The tutor's flexibility and positive attitude are shown by the tutor when the tutorial and this attitude is an important part in implementing the tutorial. Attitudes related to the tendency to respond, feel, react, the act in the face of an object or idea consistently.

Positive thinking is a source of strength and a source of freedom. A source of strength because it help to think of getting solutions that are proficient, trustworthy, and strong. Source of freedom because it will be free from suffering and negative thought environment and its influence with the physical (Elfiky, 2013). Positive thinking is an attempt to fill the spaces in the mind with positive charges that are true, good, and useful. Positive thoughts are related to the ability to control thoughts Ubaedy, (2009).

\section{e. Presentation Materials}

Presenting tutorial material through power points is a conditional requirement for students and tutors in order to sharpen the attractiveness of students. This is evidenced when the tutorial observations are made the tutors have prepared and done so with power points. The use of power point as one of the tutorial media is inseparable from educational technology which has multiple benefits in the tutorial process. The flow of media in using the tutorial is as follows 


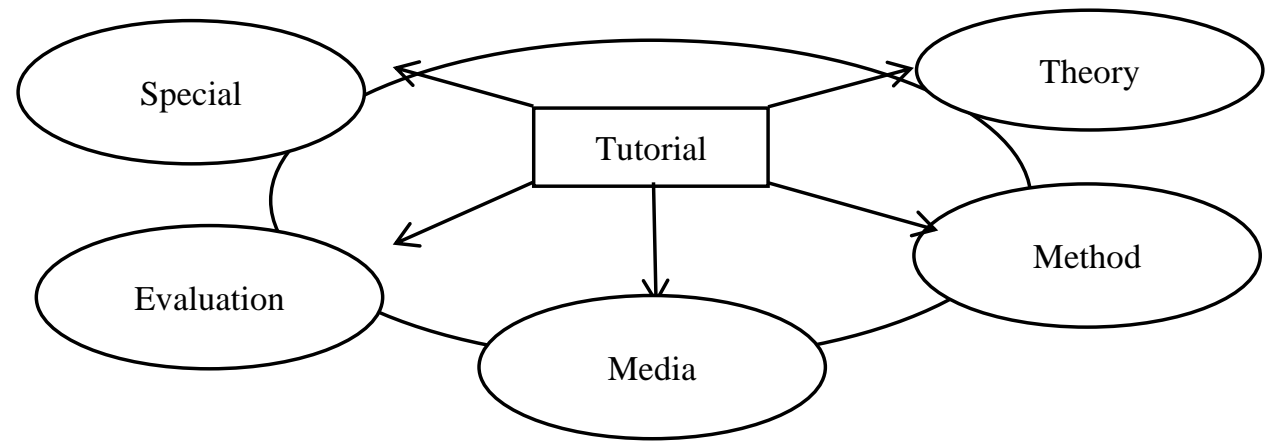

By using the media will better guarantee the occurrence of better understanding for students. The media is able to arouse and bring students into an atmosphere of pleasure and joy due to emotional and mental involvement Jalinus, (2016).

\section{f. Process Assessment, Learning Outcomes, and Closing}

The results of the observation show that the tutor conducted an assessment of the process and learning outcomes, except for the student's impression of the tutorial process, the conclusion, a review of the substance of the material with the student had not been done by the tutor during the tutorial. For example, conclusions are an accumulation of special competencies from a tutorial material must be clear and precise. Siddik (2016) any conclusions drawn must be justified or acceptable to a healthy mind. Therefore, the conclusions drawn must be based on data or the unity of the whole mind. The stability of the conclusions drawn will affect student understanding.

\section{g. Class Management Skills (CMS)}

Tutorial class management has been done well by the tutor, namely the conditions, the atmosphere of the tutorial, and handling the behavior goes well. The dynamic tutorial management of the tutor will enrich his experience of learning styles, level of understanding, time management, and students' talents and interests. Implementation of tutorial or class management, Harsanto (2007) provides an illustration of a dynamic classroom management, namely social analysis, seating patterns, material mapping, the ability to ask questions, and enforcement of class discipline.

\subsubsection{Application of Basic Skills Tutorial}

a. Basic Questioning Skills (BQS)

$\mathrm{BQS}$ is not done maximally by tutors even though BQS is very necessary in order to arouse interest and curiosity, encourage expressing opinions, and develop active learning, even though these basic questioning skills are underutilized by tutors during tutorials. Syaripuddin, n.d (2009) mentions several components of the BQS, questions asked to students must be clear and concise. For example: What is meant by the terms open and long distance. This question is adjusted to the age and mental development of students.

Next, the question of giving references. For example, students already know about open and distance education, try to mention the flexibility of recruiting prospective new students, then the questions move in turn, meaning the tutor asks questions classically, then chooses several students to answer by saying their names in turn. For example, what impressions are obtained after you learn through the online smart teacher portal. While continued questioning (CQ) is a basic continuation question that has the advantage of increasing student participation in a tutorial situation and developing student thinking skills. 
The characteristics of $C Q$, namely questions require students' thinking abilities, use tracking questions, and questions create interaction between tutors and students or between students. BL is also underutilized by tutors even though CQ is very useful for students to stimulate their thinking and creative abilities.

\section{b. Strengthening Skills (SS)}

Tutors provide good reinforcement to students by means of verbal reinforcement in the form of words or sentences. For example, "good", or "very precise", and / or "I am satisfied with your answer", while nonverbal reinforcement is in the form of movements approaching, facial expressions, and thumbs up. Rifma (2016) the benefits of giving reinforcement, namely increasing attention to learning, arousing and maintaining behavior, fostering self-confidence, and maintaining a conducive learning climate.

\section{c. Variation Skills (VS)}

Tutors do not take advantage of varied tutorial style skills so that it seems very monotonous. The monotonous tutorial style has the potential to attract less student attention. This condition is not expected to occur because it does not trigger and stimulate the attractiveness of the learning atmosphere, and develop student creativity and innovation. Nata (2009) the advantages of using varied learning styles include maintaining and increasing attention, increasing the possibility of the functioning of curiosity through investigation and exploration, forming attitudes, and encouraging conducive learning activities.

\section{d. Explaining Skills (ES)}

This KM aims to guide students to understand various tutorial materials, guide students to answer questions, involve active thinking, get feedback on students' understanding, and encourage understanding of the various reasoning processes. From the tutorial process it is known that in general the tutor can provide an explanation using good and correct language.

\section{e. Opening and Closing Skills (OCS)}

OCS is an important component that must be done by tutors when doing tutorials. TEV is a guideline for implementing tutorials per tutorial activity. In SAT it is described how tutorial program material or content is delivered to students and shows active learning interactions between tutors, students, and learning resources. The opening and closing tutorial activities are in the tutorial event unit (TEV) so that tutors can do it systematically (Karuru, 2004).

\section{f. Skills for Guiding Small Group Discussions (SGSGD)}

SGSGD an important part of the tutorial process that is measurable and systematic because with a measurable and systematic SGSGD it will provide more convenience, smoothness, and validity of the learning process and learning outcomes. This is inseparable from the tutor's intelligence of designing SGSGD by paying attention to concentration, clarity of discussion issues, analysis of views, dissemination of participation, and closing of discussions. The application of this SGSGD is less of a tutor's attention, so the tutorial process does not seem well controlled.

\section{g. Class Management Skills (CMS)}

The creation and maintenance of interesting and conducive classroom conditions are inseparable from the tutor's creation in the tutorial class manager. Tutors can manage their tutorial classes well, even though the seating model is less varied. One of the seating model settings that can accommodate student learning interests with a tutor is the conference seating model setting. The conference seating model suggests the tutor inspects the routine of each individual per row of seating settings, so that 
the tutor and student truly create an atmosphere of conducive tutorials and stimulate active and creative thinking.

\section{Conclusion}

\section{Components of the Application of Professional Competency Tutors}

The tutors have prepared tutorial tools before carrying out the tutorial activities in the tutorial room. The tutors did not check the readiness of the student modules and did not convey the specific competency (KK) tutorials that were to be achieved in the implementation of the tutorial. The tutors in presenting the material are still not optimal. For example, not reviewing response that incorrect, not doing apperception, and not involving students in summarizing tutorial material. The attitude of flexibility and positive attitude are well demonstrated. The tutor in presenting their material used power points. The tutors in the assessment process or learning outcomes have not made student responses to the tutorial process. The presentation system, the use of Indonesian language is good and right, and the appearance of the tutor is shown well when giving a tutorial.

\section{Components of Application of Basic Skills Tutorial}

The tutors did not use the basic questions to ask students, that the submission of classical questions was not carried out so that the tutors seemed to have a monopoly on time. Likewise, the follow-up question, the tutor did not do it so that it appears that students cannot develop their thinking skills, cannot stimulate their thinking and creativity in expressing their opinions. Tutors can do verbal and nonverbal reinforcement in the tutorial process. The tutors did not take advantage of the varied tutorial styles so that the tutorial process did not seem to get the attention or a good response from students. The tutorial process is less interactive between tutors and students, or students and students. The tutors make good explanations in correct, good, and clear language and the language of the tutor is easily understood by students. The tutors did the opening and closing tutorial well even though the information items that were delivered were not done in full. The tutors conduct group discussions well, it's just not done systematically and not measured so that the value obtained by students at the level of speculation. The tutors manage the class without real attention so that the classroom management is impressed as it is. During the tutorial process the tutor never checks the attention of students towards the ongoing learning process.

\section{Recommendation}

To get professional quality tutors, tutors should carry out tutorial tasks referring to the design of tutorial activities (RAT) and tutorial program units (SAT) and implemented consistently and responsibly. To get a tutorial atmosphere in engaging active attention, developing mind creations, awakening selfconfidence, and working productivity of students, tutors should make use of the basic competencies of tutorials that are held seriously and are responsible for the tasks they carry.

\section{References}

Ananta, Z. (2018). Rahasia Kebiasaan Hidup Orang Sukses dan Kaya Yang Tidak Dilakukan Orang Biasa. KAKTUS.

Arifin, M.A. (2021). Competence, Competency, and Competencies: A Misunderstanding in Theory and Practice for Future Reference. International Journal of Research in Business and Social Science (2147-4478). September 2021. Vol. 11, No. 9, 2021, Pg. 755 - 764. DOI: 10.6007/IJARBSS/v11-i9/11064

Arifmiboy (2019). TADALURING MICROTEACHING: AN EFFECTIVE LEARNING MODEL TO DEVELOP BASIC TEACHING SKILLS. Jurnal Pendidikan Teknologi dan Kejuruan, Vol. 25, No. 1, May 2019, 141-151 ISSN: 0854-4735, accredited by KEMENRISTEKDIKTI, Decree No: 51/E/KPT/2019 DOI: DOI: 10.21831/jptk.v25i1.23157 
Arief, Z. A., \& Srihastuti, E. (2017). Hubungan antara Persepsi Siswa tentang Penggunaan Peta Indonesia dan Minat Belajar dengan Hasil Belajar IPS Siswa Kelas V SDN Ciangger 02. Jurnal Teknologi Pendidikan, 6(2).

Ashton, A. H. (1991). Experience and error frequency knowledge as potential determinants of audit expertise. Accounting Review, 218-239.

AlMegbil,T. $\quad$ (2020). Small group teaching. https://www.researchgate.net/publication/339352316_Small_group_teaching/link/5f44eec6299bf13404f1ca52/do wnload

Bertens, K. (1993). Etika K. Bertens (Vol. 21). Gramedia Pustaka Utama.

Brown, S., \& Race, P. (2013). 500 Tips for Tutors. Routledge.

Bungin, B. (2007). Analisis data penelitian kualitatif.

Darmayanti, T., \& Sumantri, D. E. (2004). Pengembangan tutorial melalui media telepon pada pendidikan jarak jauh (studi kasus di FISIP Universitas Terbuka). Jurnal Pendidikan Terbuka Dan Jarak Jauh, 5(2), 108-127.

Deswita, D. (2017). PROFIL TINGKAT PENGUASAAN KETERAMILAN DASAR MENGAJAR MAHASISWA PENDIDIKAN MATEMATIKA UNIVERSITAS PASIR PENGARAIAN. JURNAL GANTANG Vol. II, No. 1, Maret 2017 p-ISSN. 2503-0671, e-ISSN. 2548-5547

Endang S. dkk. 2014. Panduan Micro Teaching Untuk Dosen, Mahasiswa dan Crew. Surabaya: Unesa University Press. Elfiky, I. (2013). Terapi berpikir positif. Penerbit Zaman.

Fip-Upi, T. P. I. P. (2007). Ilmu dan aplikasi pendidikan. Bandung: Imperial Bhakti Utama.

Fraenkel, J. R., Wallen, N. E., \& Hyun, H. H. (2012). How to design and evaluate research in education.

Gadušová, Z..,Hašková,A.,Predanocyová P.(2019). Teachers' professional competence and their evaluation. University, 949 74, Nitra, Slovakia, Образование и саморазвитие. Том 14, № 3, 2019. doi: 10.26907/esd14.3.02

Han, S.M, Parkes P. , \& Susannah Wang (2021). Assessing "How to Ask Questions" - Response to: Is Asking Questions on Rounds a Teachable Skill? [Letter]. Dove Press journal: Advances in Medical Education and Practice.

Harsanto, R. (2007). Pengelolaan kelas yang dinamis. Yogyakarta: Kanisius.

Jalinus, N. (2016). Ambiyar. Media dan Sumber Pembelajaran. Jakarta: Kencana.

Karuru, P. (2004). Pengembangan perangkat tutorial berorientasi pembelajaran kooperatif. Jurnal Pendidikan Terbuka Dan Jarak Jauh, 5(1), 34-45.

Melih CATTIK \& Serhat ODLUYURT (2017). The Effectiveness of the Smart Board-Based Small-Group Graduated Guidance Instruction on Digital Gaming and Observational Learning Skills of Children with Autism Spectrum Disorde. TOJET: The Turkish Online Journal of Educational Technology - October 2017, volume 16 issue 4

Luthfiyah N.,Astuti, N., Romadhoni,I.F. Purwidiani,N. Handajan, Sri. (2019). STUDENTS' SKILLS IN MAKING QUESTIONS, ARE THEY INDICATORS OF THEIR THINKING SKILLS?. IEEE Eurasia Conference on IOT, Communication and Engineering. DOI: 10.1109/ECICE47484.2019.8942761

Lasmahadi, A. (2000). Sistem Manajemen SDM Berbasis Kompetensi. Tersedia Secara Online Di: Www. Epsikologi. Com [Diakses Di Bandung, Jawa Barat, Indonesia: 10 Januari 2019].

Maki, Z.T. (2021). Professions and Professionalisation. DOI:10.13140/RG.2.2.19526.60485. https://www.researchgate.net/publication/35032829 University of Basrah- Al Zahraa College of Medicine

Merriënboer, V., J.J.; Kirschner, P.A. (2017).Ten Steps to Complex Learning: A Systematic Approach to FourComponent Instructional Design; Routledge: London, UK, 2017. 
Zaidin, M., Kusmaladewi, K., \& Thaba, A., (2021). Analysis of professional competencies and basic skills in distance education tutor tutorials. Cypriot Journal of Educational Science. 16(6), 3168 - 3183. https://doi.org/10.18844/cjes.v16i6.6531

Moerdianto, Microteaching. Yogyakarta: Universitas Negeri Yogyakarta, 2017.

Muhlis H. Usman, Agil Al Idrus1, Aris Doyan, Harry Soeprianto, Aliefman Hakim (2021). Teacher Basic Skills in Learning Science in Junior High Schools Facing the 21st Century Journal of Research in Science Education, July 2021, Volume 7, Issu 3: 331-334 332. DOI: 10,29303/jppipa,v713.652

Muhidin, A. (2017). Statistika pendidikan: pendekatan berbasis kinerja. Unpam Press.

Nata, A. (2009). Perspektif Islam tentang Strategi Pembelajaran, Edisi Pertama. Cet. I.

Pupíková,E., Gonda,D. Kitti Páleníková,K., Medov ,J., Kolárová, D. \& Tirpáková, A. (2021). How Kindergarten Teachers Assess Their Own Professional Competencies. Educ. Sci. 2021, 11, 769. https://doi.org/10.3390/educsci11120769

Rahayu,R.\&Susanto,R.(2018). PENGARUH KEPEMIMPINAN GURU DAN KETERAMPILAN MANAJEMEN KELAS TERHADAP PERILAKU BELAJAR SISWA KELAS IV. Jurnal Pendidikan Dasar PerKhasa Volume 4, Nomor 2, Oktober 2018

Rifma, M. (2016). Optimalisasi Pembinaan Kompetensi Pedagodik Guru: Dilengkapi Model Pembinaan Kompetensi Pedagogik Guru. Kencana.

Richard J. Shavelson (2014). What Is The Basic Teaching Skill?. Journal of Teacher Education. DOI: $10.1177 / 002248717302400213$

Samini, T. (2019). Computer Based Instruction Model Drill Tingkatkan Hasil Belajar TIK Materi Rumus Dan Fungsi Dalam Microsoft Excel. Prosiding Seminar Nasional PEP 2019, 1(1).

Santoso, S. (2018). Konsep dasar dan Aplikasi SEM dengan AMOS 24. Elex Media Komputindo.

Sanusi, A. (2010). Tingkat Efektifitas Penggunaan Media Website Oleh KPU Provinsi Jawa Barat Dalam Mensosialisasikan Pemilu 2009 Kepada Masyarakat (Studi Kasus Kelurahan Cimahi Kecamatan Cimahi Tengah Kota Cimahi). Universitas Komputer Indonesia.

Saudagar, F. (2009). Pengembangan profesionalitas pendidik. Gaung persada (GP Press).

Siddik, M. (2016). Dasar-dasar Menulis dengan Penerapannya. Tunggal Mandiri Publishing.

Sugiyono. (2013). Metode penelitian manajemen. Bandung: Alfabeta, CV.

Susanto, H. (2012). Faktor-faktor yang mempengaruhi kinerja guru sekolah menengah kejuruan. Jurnal Pendidikan Vokasi, 2(2).

Sutrisna, I. P. G., \& Susanta, I. P. A. E. (2020). EKSPRESI TUTURAN PENOLAKAN SISWA TUNA RUNGU DALAM WACANA AKADEMIK (KAJIAN PRGMATIK KLINIS). Jurnal Membaca Bahasa Dan Sastra Indonesia, 5(2).

Suwendra, I. W. (2018). Metodologi penelitian kualitatif dalam ilmu sosial, pendidikan, kebudayaan dan keagamaan. Nilacakra.

Syaripuddin, M. M. (n.d.). Sukses Mengajar Di Abad 21:(Keterampilan Dasar Mengajar Dan Pendekatan Pembelajaran K13). Uwais Inspirasi Indonesia.

Thoha, N., \& Hutapea, P. (2008). Kompetensi Plus, Teori, Desain, Kasus dan Penerapan Untuk HR serta Organisasi yang dinamis. Jakarta: PT Gramedia Pustaka Utama.

Ubaedy, A. N. (2009). Cerdas mengasuh anak. Jakarta Selatan: KinzaBooks.

Zdenka G., Alena H.\& Ĺubica P. (2019). Teachers' professional competence and their evaluation. University, 949 74, Nitra, Slovakia, Образование и саморазвитие. Том 14, № 3, 2019. doi: 10.26907/esd14.3.02 